Volume 10 No. 2 September 2019

P-ISSN 2086-6178 E-ISSN 2579-3292

http://ejournal.bsi.ac.id/ejurnal/index.php/jkom

\title{
Proses Produksi Dalam Industri Musik Independen Di Indonesia
}

\author{
Ningrum Dwi Lestari \\ London School Of Public Relations \\ e-mail: 30ningrum@gmail.com
}

Cara Sitasi: Lestari Ningrum Dwi. Proses Produksi Dalam Industri Musik Independen Di Indonesia. Jurnal Komunikasi 10 (2), 161-168.

\begin{abstract}
This research focused on production process in the music recording industry independently by musician, Andien Aisyah. Previously Andien Aisyah worked with Major Label. The concept used in this research is concept of production, and associated with the production process on the recorded music by Andien. The research method used in this research is descriptive qualitative research. The results of the analysis of the production process recording music album by Andien independently has several similar stages to the production process previously with Major Label. In the production process between Major Label and Indie Label there is a difference that is in the pre-production stage, the difference is from the freedom of creativity to create music that will be produced. The freedom is a reason for Andien to move from Major Label to Indie Label. The freedom of creativity on the music recording independently is a form musician resistance against the Major Label which restrict the creativity of their musical works.
\end{abstract}

Keywords : Mass media, music recording industries, Major Label, Indie Label

\section{PENDAHULUAN}

Musik merupakan hal yang banyak digemari oleh masyarakat di dunia termasuk Indonesia. Keberadaan musik sudah menyatu di kehidupan masyarakat dan memiliki peranan penting yang sulit dipisahkan dari sebagian masyarakat. Sejak dulu musik sudah menjadi sarana yang efektif dalam mengekspresikan jiwa, melakukan ritual keagamaan, hiburan, sarana ekonomi, dan juga dapat menjadi sarana penyampaian pesan dalam berkomunikasi di masyarakat.

Pola suara yang dihasilkan mudah dimengerti dan dipahami, musik telah menjadi bahasa universal bagi setiap umat manusia. Setiap orang bisa menikmati musik tanpa harus mengetahui dari mana musik itu berasal dan apakah kita mengerti bahasa yang digunakan dalam suatu lagu. (Zulhidayat \& Ruhimat, 2013)

Musik yang memiliki peran sebagai sarana penyampaian pesan dalam berkomunikasi memiliki efektivitas dalam mewakilkan kondisi sosial maupun pribadi masyarakat melalui kemampuan berpikir dan daya cipta yang sangat kreatif. Kemampuan daya pikir masyarakat yang kreatif tersebut melahirkan berbagai pekerja kreatif seperti musisi serta orangorang di belakang layar yang membantu keberhasilan suatu karya milik musisi tersebut.
Melihat eksistensi musik saat ini yang sudah menjadi bagian dari sebuah industri para musisi perlu terjun langsung ke dalam dunia industri rekaman musik itu sendiri. Perkembangan industri rekaman musik di Indonesia saat ini menjadi sangat beragam. Keberagamannya terlihat dari munculnya kategori pada industri rekaman musik yang saat ini cukup dikenal masyarakat yaitu industri rekaman musik seperti Major Label dan Indie Label.

Major Label juga biasa disebut sebagai industri musik rekaman yang mainstream. Menurut Wenz yang dimaksud mainstream adalah arus utama, tempat band-band yang bernaung di bawah label besar, sebuah industri yang mapan. Band-band tersebut dipasarkan secara meluas yang coverage promosinya juga secara luas, nasional maupun internasional, dan mereka mendominasi promosi di seluruh media massa, mulai dari media cetak, media elektronik hingga multimedia dan mereka terekspos dengan baik. (Resmadi, 2017)

Indie Label sering diartikan sebagai singkatan dari kata "independent" yang berarti bebas sebebasbebasnya. Indie Label terlihat cerdik dan pintar, dengan trik yang bisa membuat ngiler si raksasa; seringkali Indie Label lebih cepat merespon tren baru dan lebih idealis dalam tujuannya. Dan dikenal sebagai sesuatu yang berbeda karena cenderung 
karakternya eksperimental, amatir, atau cutting edge dan sebagainya. (Resmadi, 2017)

Rekaman melalui Indie Label kini banyak diikuti oleh sebagian musisi yang memperjuangkan hasil karyanya secara independen tanpa ingin ada campur tangan Major Label. Musisi tersebut melakukan proses produksi konten musik dengan bebas secara mandiri, dimulai dari tahapan kreatif hingga musik tersebut siap untuk dipasarkan.

Berdasarkan artikel dari Kompas.com yang bekerja sama dengan web infografik Ziliun tertulis bahwa, memang sebagian musisi menggunakan jalur indie karena memang tidak atau belum punya akses ke media mainstream, tapi sebagian lainnya memang memilih indie karena mereka tidak mau diatur pasar dan korporat besar yang hanya ingin jualan dan dapat untung. Mereka tidak mau diatur dan disuruh membuat lagu yang mereka tidak suka hanya karena ada target penjualan. Ada banyak sekali musisi Indonesia yang bagus dan memilih untuk berkarya di jalur independen. Tapi itu sama sekali tidak membuat prestasi mereka tidak kedengaran. Justru mereka banyak diapresiasi oleh komunitas musik, baik di dalam sampai di luar negeri. (Izzati, 2014)

Kebebasan musisi dalam berkarya melalui jalur independen menarik perhatian untuk diidentifikasi lebih lanjut terhadap proses produksi dalam industri rekaman musik Indie Label. Penelitian ini dilakukan karena tahapan kreatif dalam sebuah industri musik terletak pada proses produksinya, yang dimana proses produksi industri rekaman musik di Indie Label memberikan kebebasan para musisi dalam hal kreativitas, sehingga dari hasil produksi musik tersebut dapat menjadi acuan apakah hal itu merupakan sebuah jalan pintas bagi para musisi untuk berkarya, melihat semakin banyak musisi yang saat ini memilih berada di jalur independen.

Beberapa hal tersebut datang dari kejadian yang terdapat dalam dunia industri musik rekaman, yaitu adanya musisi yang melakukan perpindahan label rekaman dari Major Label ke Indie Label. Sejumlah musisi yang memutuskan untuk pindah label ke jalur independen adalah Naif, Sheila on 7, dan Project Pop. Namun selain itu, sudah ada musisi-musisi seperti Slank (Slank Record) Glenn Fredly (Musik Bagus) dan Sandhy Sandoro (Sondoro Music) yang memiliki label sendiri. Ini seolah mempertegas bahwa Major Label bukan menjadi satu-satunya jalan buat para musisi untuk menelurkan karya dan bisa sampai ke para pendengar terutama fans. (Boeton, 2017)

Salah satu musisi lainnya yang melakukan perpindahan label adalah Andien, yang sebelumnya berada di bawah naungan Major Label. Andien telah berkarya di bawah naungan Major Label selama 17 tahun dan sudah memiliki enam karya album musik, namun pada pembuatan album ketujuh miliknya ia memutuskan untuk memproduksinya secara independen.

Berdasarkan artikel yang ditulis oleh JawaPos.com, Andien mengatakan bahwa, dirinya tidak perlu memikirkan bagaimana pandangan orang mengenai lagu tersebut. Andien ingin berkarya sejujurnya, tanpa ada yang membatasi. Andien telah sampai pada titik dimana dirinya harus melihat lagi kebelakang mengenai tujuan ia bernyanyi. (Ded, 2017)

Saat ini melalui jalur independen musisi dapat lebih bebas berkarya tanpa harus dibatasi dari pihak label. Keputusan yang dipilih oleh musisi tersebut tentunya memiliki keterkaitan dengan proses produksi dalam industri rekaman musik Indie Label. Melihat dari bagaimana keadaan proses produksi yang dilakukan oleh tiap label rekaman apakah hal tersebut juga menjadi faktor musisi untuk memutuskan menggunakan Indie Label sebagai proses dalam melakukan produksi konten musik mereka.

Alasan Andien untuk mengerjakan album secara independen yang ingin berkarya tanpa ada yang membatasi, menarik perhatian untuk ditelusuri lebih lanjut seperti apa proses produksi yang Andien lakukan secara independen, dan bagaimana perbedaan dalam proses produksi pada saat ia di Major Label dan Indie Label.

Dari permasalahan ini dapat dirumuskan sebagai pertanyaan dalam penelitian ini: Bagaimana proses produksi dalam industri rekaman musik independen, apakah dengan produksi industri rekaman musik secara independen mempengaruhi musisi dalam memproduksi musik sehingga menjadi alternatif mereka dalam berkarya.

\section{Proses Produksi}

Dalam buku What is Music Production? tertulis mengenai identifikasi dari proses produksi tahap kasar dari proses produksi untuk menghasilkan karya kreatif, sebuah ide harus berkembang, atau keinginan untuk menangkap pengalaman. (Hepworth-Sawyer \& Golding, 2011)

Produksi musik adalah teknologi tambahan dari komposisi dan orkestra. Hal ini untuk mendapatkan kesuluruhan komposisi, orkestrasi, dan tampilan dari komposer. Dalam ketepatan dan kemampuannya yang melekat untuk menggambarkan budaya, individu, lingkungan, timbral, dan interpretatif bersama dengan intonasi, waktu, niat, dan makna, hal tersebut lebih unggul dari musik tertulis dan tradisi lisan. Produksi musik tidak hanya 
representasional tetapi juga merupakan seni tersendiri. (Burgess, 2013)

\section{Pra-Produksi}

Pra-produksi hanya sebutan yang menjelaskan apa yang harus dilakukan sebelum sebuah "produksi" dimulai. Berikut ini adalah "produksi" yang dalam istilah musik dianggap sebagai sesi pencatatan dan pencampuran yang dikumpulkan bersama, meski seringkali menjadi proses tersendiri. Begitu campuran itu tercapai, ia beralih ke pasca-tproduksi, yang dalam hal industri musik berarti editing dan mastering. (Katz \& Hepworth-Sawyer, 2009)

Pra produksi adalah salah satu tahap tersembunyi yang paling banyak mengalir ke dunia luar dan nonmusikal. Ini adalah proses yang harus sesuai dengan setiap seniman dan situasi berdasarkan visi produk yang diinginkan. Bergantung pada jenis lagu, album dan artis, pra-produksi bisa mengambil berbagai bentuk. Oleh karena itu, pra produksi adalah jembatan antara komposisi musik dan sesi rekaman, keterampilan dan tugas meminjam yang secara tradisional dicadangkan pada tahap lain dalam prosesnya. (Katz \& Hepworth-Sawyer, 2009)

Pra produksi merupakan tahapan produksi yang di dalamnya terdapat proses kreatif dari pembuatan lagu milik para musisi. Pada buku (Katz \& Hepworth-Sawyer, 2009) yang berjudul The Mastering Music Series, terdapat enam hal proses kreatif dalam pra produksi rekaman musik yaitu:

\section{Pengembangan lagu}

Mengembangkan lagu secara maksimal dapat membutuhkan waktu dan memerlukan bahan-bahan khusus. Cara tradisional sebuah band rock, proses penulisan lagu akan dimulai oleh anggota band di rumah atau di bus tur dan dikembangkan lebih lanjut ketika dibawa dalam latihan. Pengembangan materi bersama banyak dilakukan di studio pada saat latihan. Anggota band diperkenalkan ke materi baru dan kemudian mengembangkan ide-ide baru termasuk riff, irama, harmoni, dan lain sebaginya termasuk bagian yang baru.

2. Kepentingan yang diperbarui di ruang latihan dan home studio

Latihan menjadi peluang penting untuk memperbaiki struktur dan pengaturan lagu. Arsitektur emosional dalam pengaturan menggunakan dinamika dan konten harmonik harus diteliti dan disesuaikan agar sesuai dengan tampilan musisi serta kelemahannya.

\section{Merekam latihan}

Merekam latihan dapat memungkinkan band mendengar bagaimana suara yang mereka hasilkan. Sangat sering terjadi bahwa musisi itu sendiri mendapatkan persepsi yang berbeda tentang kinerja mereka di dekat amplifier mereka di panggung.
Seringkali band dapat kehilangan perspektif yang diperlukan ketika membangun dan memproduksi lagu. Selain itu, lagu bisa menjadi lebih terstruktur untuk dikembangkan.

\section{Parameter perubahan}

Perubahan dan rekomposisi unsur-unsur seperti melodi, harmoni, dan sebagainya adalah bentuk parameter pengembangan lagu. Metode dan urutan perkembangan yang terjadi tidak dapat ditentukan oleh produser, atau pendengar obyektif lainnya, mungkin pendapat mereka berdasarkan pada perasaan. Mereka mungkin mendengar suara atau pengaturan yang berbeda dan menyarankan perubahan yang sesuai. Pengembangan lagu bergantung pada sejumlah kriteria kritis dari daftar hal pribadi yang orang cari.

5. Kemampuan untuk mendengarkan secara objektif

Untuk membuat penilaian musik yang akurat, penting untuk mengembangkan keterampilan tertentu dalam mendengarkan. Bentuk perencenaan diuraikan untuk keterampilan produksi dan kemampuan mendengarkan memungkinkan untuk mengidentifikasi apakah materi yang sudah disiapkan sesuai dengan rencana. Kemampuan dalam mendengarkan yang lebih baik harus memastikan bahwa masalah dalam suatu komposisi atau susunannya dapat diidentifikasikan atau dirubah.

\section{Mengurangi materi}

Mengurangi materi dalam proses pra produksi ini adalah memilih materi lagu yang akan direkam. Band dapat mendengarkan refleksi dari beberapa materi mereka, yang mungkin dapat ditampilkan (direkam).

\section{Produksi}

Tahap produksi dalam industri rekaman musik adalah tahapan rekaman yang sebenarnya dari seluruh materi yang sudah direncanakan. Tahap ini secara konvensional meliputi pelacakan dan overdubbing dan biasanya dapat melibatkan sejumlah orang, penulis lagu, musisi, teknisi dan produser semua memberikan masukan kreatif mereka. (Zagorski-Thomas, 2016)

Tahapan produksi ini melibatkan semua kegiatan yang berkaitan dengan persiapan untuk pasar, mulai dari melatih, merekam dan mencampur musik dengan anggaran dan mengatur hak cipta. Produksi melibatkan sekelompok individu yang luas mulai dari seniman sendiri hingga penulis lagu, arrangers, sound engineers, dan banyak lagi, yang semuanya memberikan kontribusi kreatif untuk produk hingga selesai. (Kung, 2008) 


\section{Pasca Produksi}

Pasca produksi adalah fase seluruh rancangan sudah menjadi bagian yang lengkap. Ini adalah tahap di mana mixing, editing, dan mastering terjadi. Mixing adalah perpaduan berbagai suara menjadi kohesif yang memenuhi berbagai kriteria musik dari teknis, komersial, hingga kriteria pribadi. Editing adalah tahapan dimana materi yang tidak diinginkan dapat dihapus, kemudian kesalahan dapat diperbaiki dan menyusun ulang kembali ide. Mastering adalah tahapan Pasca-produksi yan dimana keseluruhan produksi akhir disesuaikan dalam hal dinamika, pemerataan dan pengurangan suara yang mengganggu sehingga enak terdengar di seluruh sistem pemutaran audio. (Zagorski-Thomas, 2016)

\section{Major Label}

Major Label adalah perusahaan rekaman besar yang mampu mencakup wilayah internasional. Untuk mendapatkan gambaran tentang keadaan bisnis rekaman internasional adalah dengan melihat empat perusahaan rekaman terbesar yaitu Universal, Sony BMG, Warner, dan EMI, bahkan sebagian berbasis di Amerika Serikat dan satu di Inggris. "Berpikir global; bertindak lokal" adalah kalimat yang digunakan oleh para eksekutif industri rekaman. Perusahaan besar berkonsentrasi mengambil musik hits Amerika dan Inggris dan membuatnya menjadi sukses diseluruh dunia. (Turow, 2009)

Banyak kritik menyuarakan keprihatinan atas konglomerasi dan internasionalisasi dalam bisnis musik, kekhawatiran yang berpusat pada nilai budaya tradisional musik. Para konglomerat biasanya tidak memberontak dalam selera budaya mereka, dan mereka juga biasanya tidak mau mengambil risiko terhadap ide-ide baru. Homogenisasi budaya merupakan hal mengkhawatirkan yang mempengaruhi dunia rekaman yang dikendalikan oleh beberapa raksasa yang berorientasi pada keuntungan. Jika band atau artis tidak memiliki potensi, mereka tidak ditandatangani. Jadi seniman turunan dan kelompok manufaktur mendominasi. (Baran, 2013)

Wendi Putranto (dalam Rolling Stone Music Biz, 2009) mengatakan bahwa sebagai investor maka kontrol label (Major Label) atas karya musik yang diciptakan artis akan semakin besar. Dalam artian, suka atau tidak suka, artis harus tunduk kepada keinginan dan arahan label jika karier mereka ingin berkembang dan mendapat prioritas utama. (Putranto, 2009)

Dari penjelasan di atas mengenai Major Label terlihat bahwa label tersebut merupakan sebuah perusahaan rekaman yang di mana hasil produksi mereka mampu mendominasi industri musik di dunia termasuk Indonesia. Major Label dalam memproduksi karya musik berdasarkan selera pasar (mainstream) agar musik tersebut laku dipasaran. Label ini juga memiliki kuasa atas artis yang berada dibawah naungan mereka.

\section{Indie Label}

Perusahaan rekaman independen biasanya dianggap sebagai perusahaan yang tidak dimiliki oleh label besar atau konglomerat. Definisi semacam itu cukup luas, mencakup segala sesuatu dari label kecil dengan beberapa artis yang memasarkan rekaman pada tingkat lokal atau regional. Sebuah label dengan artis yang mendistribusikan secara nasional melalui distributor independen, atau label yang rekamannya didistribusikan oleh label besar tetapi bukan bagian atau dimiliki label besar tersebut. Beberapa orang menganggap bahwa label independen yang pendistribusiannya melalui label besar bukanlah indie sejati, karena tidak didistribusikan melalui distributor independen, tetapi saat ini label apa pun yang tidak dimiliki oleh label major berhak atas sebutan "indie". (Business et al., 2011)

Indie fokus pada hal baru atau memiliki minat pada genre yang khusus dan memiliki peran penting dalam menemukan bakat baru. Kemajuan teknologi menghembuskan kehidupan baru dalam sektor ini. Alat instrumen dan perekam yang relatif murah memungkinkan lebih banyak musisi untuk memproduksi musik yang berkualitas tanpa studio rekaman yang profesional. (Kung, 2008)

Salah satu alasan munculnya perusahaan independen adalah bahwa teknologi rekaman digital pribadi yang baru dengan harga terjangkau telah memungkinkan perusahaan kecil untuk memproduksi compact disk. Ketersediaan teknologi ini telah menyebabkan kemunculan rekaman independen. Banyak perusahaan produksi kecil yang mengedarkan produk mereka ke toko atau menjualnya langsung di web atau di konser yang berhubungan dengan distributor utama. (Turow, 2009)

\section{METODOLOGI PENELITIAN}

Berdasarakan data dan fenomena yang terjadi metode penelitian yang digunakan dalam penelitian ini adalah metode penelitian kualitatif dengan pendekatan deskriptif. Jenis penelitian kualitatif deskriptif yang digunakan dalam penelitian ini bertujuan untuk memperoleh informasi mengenai proses produksi industri rekaman musik secara independen yang dilakukan oleh musisi dengan mendalam dan komprehensif. Pendekatan kualitatif yang digunakan dalam penelitian ini diharapkan dapat mengungkapkan situasi dan permasalahan yang ada dalam industri rekaman musik. 
Penelitian kualitatif adalah kegiatan melakukan pengamatan situasi dunia. Penelitian kualitatif terdiri dari praktek material interpretif yang melihat dunia. Praktek ini mengubah keadaan sosial, membuat keadaan sosial menjadi serangkaian representasi, termasuk catatan lapangan, wawancara, percakapan, foto, rekaman, dan memo. Pada tingkat ini, penelitian kualitatif melibatkan pendekatan interpretif, naturalistik terhadap keadaan sosial. Hal ini berarti bahwa peneliti kualitatif mempelajari halhal mengenai keadaan alam mereka, mencoba untuk memahami atau menafsirkan fenomena yang orang bawa ke mereka. (Denzin \& Lincoln, 2018)

Jenis pendekatan penelitian ini adalah deskriptif. Penelitian deskriptif, penelitian yang tujuan utamanya adalah untuk "memberikan gambaran" dengan menggunakan kata-kata dan angka serta untuk menyajikan persoalan, klasifikasi jenis, atau garis besar tahapan guna menjawab pertanyaan seperti siapa, kapan, dimana, dan bagaimana. (Neuman, 2013)

\section{HASIL DAN PEMBAHASAN}

\section{Hasil Analisis Berdasarkan Proses Produksi Rekaman Musik.}

Dalam industri rekaman musik Major Label maupun Indie Label terdapat proses produksi, proses produksi yang dilakukan tentunya berkaitan dengan musik yang akan dihasilkan. Produksi dalam industri musik juga melalui tahapan-tahapan mulai dari pra produksi, produksi, dan pasca produksi. Saat ini dalam proses produksi antara Major Label maupun Indie Label hampir memiliki kesamaan.

Perkembangan teknologi dan informasi membuat proses produksi dalam industri musik Major Label maupun Indie Label sepadan. Teknologi yang serba digital mempermudah musisi memproduksi karyanya dengan modal yang terbilang murah, karena tidak perlu menggunakan cara lama seperti pada era analog (era piringan hitam) yang dalam produksinya sangat perlu modal besar. Kini proses produksi musik secara independen bahkan dapat dengan mudah dilakukan di rumah musisi itu sendiri.

\section{Tahap Pra Produksi Rekaman Musik}

Tahapan pra produksi yang dilakukan dalam sebuah industri rekaman musik dimulai dari workshop. Workshop untuk produksi sebuah rekaman musik adalah kegiatan di mana para musisi membicarakan dan mulai mengolah karya cipta yang akan mereka rekam. Pada tahapan pra produksi ini artis yang berasal dari sebuah band dan artis solo terdapat perbedaan. Masing-masing musisi sudah memiliki ketentuan tersendiri dalam tahap pra produksi yang mereka lakukan.
Dalam kegiatan workshop produksi musik adalah proses penulisan lagu atau pembuatan lagu yang akan direkam. Namun proses penulisan lagu antara band dan artis solo terdapat perbedaan yaitu penulisan lagu dari proses produksi musik sebuah band dilakukan secara bersama-sama. Para personil memiliki tanggung jawab masing-masing dalam menciptakan lagu yang dimana dalam penciptaannya dapat dilakukan dengan memainkan musik bersama di studio ataupun di rumah mereka masing-masing dengan alat musik yang mereka mainkan. Setiap personil membuat basic track atau not dasar dari alat musik yang mereka mainkan, setelah itu jika sudah dapat not dasar dari lagu yang mereka ciptakan lalu mereka memainkan secara bersama-sama di studio.

Kemudian untuk tahap penulisan lagu pada artis atau musisi solo perbedaannya yaitu bahwa artis solo tidak melakukan penulisan lagu sendirian, namun mereka memiliki pencipta lagu yang profesional dan sudah memiliki produsernya sendiri. Untuk aransemen lagunya, artis solo menggunakan pemain musik tambahan yang profesional seperti memilih sendiri musisi yang akan mengisi suara instrumen lagunya. Lagu tersebut diciptakan oleh pencipta lagu yang profesional lalu ditunjukkan ke artis yang meminta dan artis pun memberikan saran atas lagu tersebut.

Pada tahap pra produksi juga terdapat bagian membuat panduan musik, panduan musik tersebut adalah sebuah petujunjuk untuk musisi dalam membuat musik yang akan direkam. Pembuatan panduan musik dilakukan untuk mengaitkan antara musik yang telah dibuat sebelumnya dan sebagai petunjuk untuk musik yang akan dimainkan dengan pemainnya. Pada saat proses rekaman, musisi-musisi tersebut juga mendengarkan petunjuk dari musik yang akan direkam agar sesuai.

\section{Tahap Produksi Rekaman Musik}

Proses produksi dalam rekaman musik adalah proses rekaman itu sendiri. Tahapan rekaman yang dilakukan para musisi biasanya dimulai dari perekaman suara alat musik drum untuk seluruh lagu dalam satu album. Setelah perekaman suara alat musik drum, kemudian rekaman bass, dan baru masuk gitar serta alat musik tambahan lainnya sesuai komposisi yang telah ditentukan musisi.

Merekam suara artis biasa dilakukan pada tahap rekaman suara yang terakhir ketika seluruh instrumen musik sudah selesai direkam. Pada tahap proses rekaman ini teradapat beberapa orang yang terlibat seperti produser, asisten produser, dan sound engineer. Sound engineer merupakan teknisi yang membantu para personil atau musisi dalam melakukan rekaman suara alat musik mereka dan 
biasanya tiap personil atau musisi yang memainkan musik memiliki teknisinya masing-masing.

Tahap Pasca-Produksi Rekaman Musik

Tahap pasca produksi rekaman musik adalah merupakan proses terakhir dari sebuah produksi rekaman musik. Pada tahap pasca produksi ini terdapat dua kegiatan yang selalu dilakukan oleh seluruh musisi dalam memproduksi musik mereka, dua kegiatan tersebut adalah mixing dan mastering.

Pada proses pasca produksi itu merupakan proses editing dari musik yang telah direkam secara digital. Setelah diedit musik tersebut dimixing yang merupakan proses menyatukan lagu dengan memasukan instrumen lainnya ke dalam musik tersebut. Proses edit dan mixing dilakukan oleh dua kru yang berbeda yaitu terdapat editor untuk mengedit hasil rekaman dan sound engineer untuk mixing musik yang telah diedit. Setelah melakukan tahap mixing, musik tersebut masuk ke dalam tahap mastering, ketika selesai melakukan tahap mastering maka proses produksi rekaman musik pada tahap pasca produksi sudah selesai.

Hasil Analisis Berdasarkan Produksi Rekaman Musik Major Label

Produksi rekaman musik melalui Major Label tentunya memberikan pengaruh kepada musisi yang melakukan produksi rekaman musik di bawah naungan mereka. Pihak label yang mempengaruhi musisi dalam produksi musik merupakan sebuah kontrol terhadap produksi musik yang dilakukan oleh musisi itu sendiri.

Pengaruh yang ada dalam Major Label adalah sebuah kontrol terhadap karya yang akan dirilis oleh musisi mereka. Mengingat Major Label adalah perusahaan rekaman besar dengan modal yang besar maka mereka ingin mendapatkan keuntungan yang sepadan dari musisi yang mereka tangani. Strategi mereka dalam mendapatkan keuntungan besar dari hasil produksi musik musisi tersebut yaitu dengan mengurangi kerugian melalui kontrol mereka terhadap karya yang akan diproduksi sehingga segala macam proses produksi rekaman musiknya termasuk kreatifnya juga diawasi pihak label.

Kebutuhan-kebutuhan dari pihak label yang harus mengikuti tren serta keinginan pasar mempengaruhi musisi dalam melakukan produksi rekaman musiknya. Pengaruh dari pihak Major Label tentu tidak terlepas dari ketentuan-ketentuan yang pihak label buat, dalam proses produksi yang dilakukan Major Label kreativitas musisi dalam melakukan rekaman musik sangat dibatasi sesuai keinginan dari pihak label yaitu A\&R (Artist\&Repertoir) yang bertanggung jawab menentukan lagu-lagu yang tepat untuk musisi tersebut.

\section{Hasil Analisis Berdasarkan Produksi Rekaman Musik Independen}

Menciptakan karya musik yang dilakukan secara mandiri biasa juga disebut dengan produksi rekaman musik independen. Perkembangan produksi rekaman musik secara independen kini sudah jauh lebih maju bersama perkembangan teknologi rekaman dan teknologi informasi. Perkembangan teknologi tersebut mempengaruhi produksi rekaman musik secara independen.

Perkembangan teknologi yang sudah maju mempengaruhi proses produksi, distribusi, dan konsumsi dalam industri rekaman musik. Hal tersebut mempermudah serta menguntungkan musisi-musisi yang berada di jalur independen. Proses rekaman serta penyebaran hasil dari karya musik mereka jadi lebih murah dengan memanfaatkan sosial media yang ada.

Perkembangan teknologi yang mempengaruhi proses produksi rekaman musik secara independen menjadi salah satu faktor musisi memilih jalur independen. Alasan musisi yang memilih jalur independen datang dari sebuah penolakan pihak label atas demo musik yang diserahkan ke label dengan alasan musik tersebut kurang menjual. Namun saat ini musisimusisi dapat dengan mudah dan murah memproduksi musik mereka sesuai idealisme mereka dan itu merupakan kesempatan para musisi untuk menunjukkan hasil karya musik mereka.

Produksi rekaman musik yang mudah dan murah menjadi modal awal bagi para musisi, sebelum teknologi berkembang maju terdapat perbedaan antara Major Label dan independen dalam segi modal. Dalam proses produksi antara Major Label dan independen terdapat pada seberapa besar modal yang dimiliki dari masing-masing label tersebut. Saat ini musisi sudah mampu membiayai produksi yang mereka lakukan sendiri agar dapat memiliki hak cipta secara penuh atas karya musiknya. Segala hal yang mereka tentukan untuk produksi rekaman musik mereka, mereka akan membayarnya sendiri.

Selain itu perbedaan yang terdapat pada Major Label dengan independen adalah pada proses kreatifnya. Proses kreatif yang dibatasi pihak label juga membuat musisi memilih jalur independen sebagai wadah mereka untuk menunjukkan idealisme mereka dalam karya musik yang mereka buat. Jalur independen tidak hanya dipilih oleh musisi yang sejak awal karir bermusiknya ingin memproduksinya sendiri, namun juga dipilih oleh musisi yang sudah pernah berada di bawah naungan label besar.

Pihak Major Label selalu mengawasi setiap pergerakan musisi dalam memproduksi albumnya, seperti menentukan arah produksi musik termasuk konten lagu untuk album tersebut. Kemudian proses 
produksi rekaman musik secara independen musisi dibebaskan untuk memproduksi lagu mana yang terlebih dahulu ingin diproduksi, dan ketentuan dari perilisan lagu tersebut dapat berubah-ubah sesuai konten dan keinginan musisi tersebut. Sedangkan saat bersama Major Label hal-hal produksi rekaman lagu hingga perilisannya sudah disiapkan oleh pihak label dengan jelas.

\section{KESIMPULAN}

Berdasarkan hasil penelitian ini, dapat disimpulkan bahwa proses produksi dalam industri rekaman musik dari pihak Major Label yang mendominasi musisi dalam berkarya. Sehingga dalam proses produksi yang diterapkan oleh pihak label besar menyebabkan musisi untuk melakukan rekaman musik mereka musik secara independen.

Proses produksi rekaman musik yang dilakukan oleh Major Label dan Indie Label memiliki kesamaan pada tahapannya seperti, pra produksi - produksi pasca produksi. Dengan menerapkan tahapantahapan proses produksi yang sama, namun proses produksi yang dilakukan oleh Indie Label dilakukan dalam skala lebih kecil dengan pergerakan yang beba. Selain itu kedua label tersebut memiliki perbedaan yang terletak pada tahapan pra produksi yang dimana mampu menyebabkan musisi beralih ke jalur independen. Perbedaan pada tahap pra produksi tersebut yaitu merupakan kebebasan musisi dalam berkarya dan berkreasi sesuai kreativitas dan idealisme mereka.

Perkembangan industri rekaman musik secara independen yang semakin banyak diminati oleh musisi karena kebebasan dalam produksinya, memberikan pengaruh untuk musisi dalam berkarya. Hal tersebut juga mampu membuat musisi yang pernah berada di bawah naungan Major Label melakukan perpindahan ke jalur independen. Bahkan perkembangan industri musik yang dilakukan secara independen tidak hanya menjadi alternatif musisi dalam berkarya, melainkan menjadi jalan utama bagi para musisi yang sejak awal terjun ke dunia industri musik di jalur independen.

\section{DAFTAR PUSTAKA}

Baran, S. J. (2013). Introduction To Mass Communication: Media Literacy And Culture (8th ed.). New York: McGraw-Hill.

Boeton, F. (2017). Pilihan Cerdas Musisi di Jalur Indie. Retrieved January 3, 2018, from Kumparan website: https://kumparan.com/fino-boeton/pilihancerdas-musisi-di-jalur-indie

Burgess, R. J. (2013). The Art of Music Production The Theory and Practice. In Oxford University
Press (Vol. 84). Retrieved from http://ir.obihiro.ac.jp/dspace/handle/10322/393 3

Business, T. M., Industry, R., Concepts, K., Activities, I., Studies, C., Website, T. C., ... Coordinator, I. (2011). The Music Business and Recording Industry.

Ded. (2017). Ternyata Ini Alasan Andien Rilis Album Indie. Retrieved January 3, 2018, from Jawa Pos website: https://www.jawapos.com/read/2017/10/05/16 1019/ternyata-ini-alasan-andien-rilis-albumindie

Denzin, N. K., \& Lincoln, Y. S. (2018). The SAGE Handbook of Qualitative Research. Fifth Edition. In SAGE Publication (5th ed.). https://doi.org/10.1007/s11229-017-1319-X

Hepworth-Sawyer, R., \& Golding, C. (2011). What is Music Production. In What is Music Production. https://doi.org/10.1016/b978-0240-81126-0.00001-9

Izzati, P. (2014). Didukung Teknologi, Musisi Indie Indonesia Berprestasi. Retrieved from Kompas.com website: https://tekno.kompas.com/read/2014/08/07/10 100087/Didukung.Teknologi.Musisi.Indie.Ind onesia.Berprestasi

Katz, \& Hepworth-Sawyer, R. (2009). From Demo To Delivery The Process of Production. Oxford: Focal Express.

Kung, L. (2008). Strategic Management in The Media. London: Sage Publication.

Neuman, W. (2013). Metodologi Penelitian Kualitatif (7th ed.). Jakarta: PT Indeks.

Putranto, W. (2009). Music Biz Manuak Cerdas Menguasai Bisnis Musik. Bandung: Mizan Media Utama.

Resmadi, I. (2017). Music Records Indie Label: Cara Membuat Album Independen! Bandung: Dar! Mizan.

Turow, J. (2009). Media today: an introduction to mass communication. In Media (3rd ed., Vol. 25). Retrieved from http://books.google.com/books?hl=en\&lr=\&id $=\mathrm{g} 2 \mathrm{uVDTOctrkC} \&$ oi $=$ fnd $\& \mathrm{pg}=\mathrm{PR} 20 \& \mathrm{dq}=$ tur ow,+joseph+nich\&ots=HLLIZyl0f9\&sig=THo ABEJzwHgWWPFDVKNLw-yw-YY

Zagorski-Thomas, S. (2016). The Art of Record Production. In The Art of Record Production. https://doi.org/10.4324/9781315612638

Zulhidayat, I., \& Ruhimat, A. (2013). Gerbang Kreativitas: Jagat Musik. Jakarta: PT Bumi 
Aksara.

\section{PROFIL PENULIS}

Ningrum Dwi Lestari saat ini merupakan mahasiswa pasca sarjana di Sekolah Tinggi Ilmu Komunikasi The London School of Public Relations - Jakarta. 